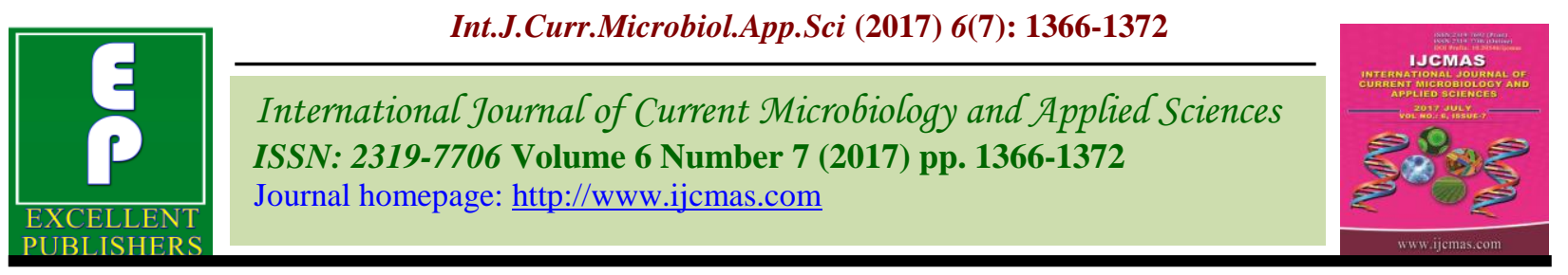

Original Research Article

https://doi.org/10.20546/ijcmas.2017.607.163

\title{
Genetic Analysis of Grain Yield and its Components of Maize (Zea mays L.) Inbred Lines
}

\author{
Padma Lay* and A.K. Razdan \\ Division of Genetics and plant breeding, Sher-e-Kashmir University of Agricultural \\ Sciences and Technology (SKUAST-J), Chatha, Jammu, India \\ *Corresponding author
}

\begin{tabular}{|c|c|}
\hline & A B S T R A C T \\
\hline Keywords & \multirow{4}{*}{$\begin{array}{l}\text { Gene action for various quantitative and qualitative traits was explored in a } \\
\text { half diallel involving seven elite inbred lines. Variance/Co-variance graphs } \\
\text { revealed that the yield potential traits like (days to } 50 \% \text { pollen shed, days to } \\
75 \% \text { brown husk, plant height ear placement height, ear length, kernel rows } \\
\text { per ear, kernel per row, test weight and grain yield,) displayed that the } \\
\text { intercept of the regression line was negative showing over dominance type } \\
\text { of gene action. Distribution of array points depicted that parents V341 \& } \\
\text { JML-109 had the maximum dominant genes while (parents CM } 212 \\
\text { \&V351) contained maximum recessive genes for most of the character. }\end{array}$} \\
\hline $\begin{array}{l}\text { Quantitative traits, } \\
\text { Over dominance, } \\
\text { Pollen shed, } \\
\text { Zea mays L, } \\
\text { Gene action, } \\
\text { Inbred line. }\end{array}$ & \\
\hline Article Info & \\
\hline $\begin{array}{l}\text { Accepted: } \\
\text { 17 June } 2017 \\
\text { Available Online: } \\
\text { 10 July } 2017\end{array}$ & \\
\hline
\end{tabular}

\section{Introduction}

Maize (Zea mays L.), the sole cultivated member of genus Zea and tribe Maydeae, ranks as one of the three important cereal crops in the world after wheat and rice. Maize being nutritionally an important crop has multiple functions in the traditional farming system, being used as food and fuel for human being and feed for livestock and poultry. It is a source of industrial raw material for production of oil, starch, syrup, gluten, alcohol, glucose, custard powder, dextrose, flour, flakes, ethanol and many more products. In Jammu and Kashmir State, maize constitutes a staple food of vast majority of rural households besides its use as livestock feed and fodder. The maize is leading crop in the state and occupies first position having largest area (308.215 thousand hectares) during kharif season with total production of 527.7 thousand metric tonnes and the productivity $1648 \mathrm{~kg} \mathrm{ha}^{-1}$ (Anonymous, 2013). Although the average yield of maize has dramatically increased in the last decade in India, an additional increase in yield will be required to meet the future needs of the country. To achieve this goal will require an efficient breeding program with well established germplasm which would provide potential exploitation of heterosis in maize germplasm developed for India. 
Different maize hybrids have been introduced from other countries into India, and inbred lines were extracted from this germplasm in order to produce successful hybrid combinations. The primary objective of most maize breeding programs is the evolution of high yielding and well adapted cultivars

\section{Materials and Methods}

The studies were conducted at the research farm of the Division of Plant Breeding and Genetics, Sher-E-Kashmir University of Agricultural Sciences and Technology Jammu, during spring 2013 and kharif 14. The lines were crossed during spring 2013 in A half diallel set that involved seven elite maize inbred lines, viz., CM212, JML-109, CML-161, V341, V345, V351 and V358. The F1seed along with their parental inbred lines were sown in randomized block design during kharif 2014 with three replications each per genotype, each plot consisting of two rows of $5 \mathrm{~m}$ length with approximately 10 plants per row. Uniform agronomic practices were applied to all the entries. Data were recorded on five representative or competitive plants for various characters for each genotype and for each replication. Data pertaining to days to $50 \%$ pollen shed, days to $50 \%$ silking, days to $75 \%$ brown husk, plant height, ear placement height, leaf width, ear length, ear girth, kernel rows per ear, kernels per row, test weight and grain yield were statistically analyzed. Characters showing significant differences among the genotypes were further analyzed for gene action by using diallel technique developed by Hayman, 1954 and Jinks, 1954.

\section{Results and Discussion}

Analysis of variance was carried out for twelve morpho-physiological traits presented in table 1 the analysis of variance revealed significant genotypic differences for all the characters studied except for the. Mean squares due to parents were found significant for all the characters except for days to $50 \%$ pollen shed, days to $50 \%$ silking, ear girth, kernel rows per ear and kernels per rows. Many workers including Hussain et al., 2009; Rana and Kapoor, 2009 reported high variation for different traits in maize. The significant differences in mean sum of squares indicated the high genetic variation for characters, hence are amenable for selection. To fulfill the assumptions such as absence of epistasis, no multiple allelism and independent assortment of genes, the data were tested through three scaling tests (regression analysis, $\mathrm{t}^{2}$ test and array analysis of variance ( $\mathrm{Wr}+\mathrm{Vr}$ and $\mathrm{Wr}-\mathrm{Vr}$ ) to evaluate the adequacy of the additive-dominance model of the data. According to Mather and Jinks (1971) the regression coefficient is expected to be significantly different from zero and not from unity. Failure of this test means the presence of epistasis. If non-allelic interaction is present, $\mathrm{Wr}+\mathrm{Vr}$ must change from array to array and similarly $\mathrm{Wr}-\mathrm{Vr}$ will vary among arrays. Non-significant values of $\mathrm{t}^{2}$ test confirm the presence of no non-allelic interaction and signify that genes are independent in their gene action for random association in genotypes.

\section{Days to $50 \%$ pollen shed}

Graphical analysis of the data (Fig. 1) displayed that the intercept of the regression line was negative cuts $\mathrm{Wr}$ axis below the origin showing over dominant type of gene action. Distribution of array points depicted those genotypes V341, V358, V345 and CM212 being nearer to the origin that possessed the maximum dominant genes for days to $50 \%$ pollen shed while genotype V351 away from the origin contained maximum recessive genes. The estimated regression line was deviated significantly from unit slope suggesting presence of allelic interaction. 


\section{Days to 50\% silking}

Graphical analysis of the data (Fig. 2) displayed that the intercept of the regression line was positive showing partial dominance type of gene action. Distribution of array points depicted that parents V351 and V345 had the maximum dominant genes for days to $50 \%$ silking while (parent JML-109 n CML161) contained maximum recessive genes. The estimated regression line was deviated significantly from unit slope suggesting of non-allelic interaction.

\section{Days to $75 \%$ brown husk}

Graphical analysis of the data (Fig. 3) displayed that the intercept of the regression line was negative showing over dominant type of gene action. Distribution of array points depicted that parents CM212 and V341 had the maximum dominant genes for days to $75 \%$ brown husk while (parent CML-161 and V345) contained maximum recessive genes. The estimated regression line was not deviated significantly from unit slope suggesting absence of non-allelic interaction.

\section{Plant height}

Graphical analysis of the data (Fig. 4) displayed that the intercept of the regression line was negative showing over dominant type of gene action. Distribution of array points depicted that parents CML-161 had the maximum dominant genes for Plant height while (Parents V345, V358 and V351) contained maximum recessive genes.

The estimated regression line was deviated significantly from unit slope suggesting presence of non-allelic interaction. The results are in in accordance with of Rafiq et al., 1993, who reported that plant height was under the control of over-dominance type of gene action.

\section{Ear placement height}

Graphical analysis of the data (Fig. 5) displayed that the intercept of the regression line was negative showing over dominant type of gene action. Distribution of array points depicted that parents CML-161 and JML-109 had the maximum dominant genes for ear placement height while (parent V358) contained maximum recessive genes. The estimated regression line was deviated significantly from unit slope suggesting presence of non-allelic interaction.

\section{Leaf width}

Graphical analysis of the data (Fig. 6) displayed that the intercept of the regression line was positive showing partial dominant type of gene action.

Distribution of array points depicted that parents CML-161 and JML-109 had the maximum dominant genes for leaf width while (parent V341) contained maximum recessive genes.

The estimated regression line was deviated significantly from unit slope suggesting presence of non-allelic interaction.

\section{Ear length}

Graphical analysis of the data (Fig. 7) displayed that the intercept of the regression line was negative showing over dominant type of gene action. Distribution of array points depicted that parents JML-109 and CML-161 had the maximum dominant genes for ear length while (parent V351) contained maximum recessive genes. The estimated regression line was not deviated significantly from unit slope suggesting absence of nonallelic interaction. 


\section{Ear girth}

Graphical analysis of the data (Fig. 8) displayed that the intercept of the regression line was positive showing partial dominant type of gene action. Distribution of array points depicted that parents CML-161 and JML-109 had the maximum dominant genes for ear girth while (parents V358, V341, V351 and V345) contained maximum recessive genes. The estimated regression line was deviated significantly from unit slope suggesting presence of non-allelic interaction.

\section{Kernel rows per ear}

Graphical analysis of the data (Fig. 9) displayed that the intercept of the regression line was negative showing over dominant type of gene action. Distribution of array points depicted that parents CML-161, V341, V358 and V345 had the maximum dominant genes for Kernel rows per ear while (parents JML-109, V351 and CM212) contained maximum recessive genes. The estimated regression line was deviated significantly from unit slope suggesting presence of nonallelic interaction.

Table.1 Analysis of variance (Mean squares) for half diallel analysis for different components in maize (Zea mays L.)

\begin{tabular}{|c|c|c|c|c|c|c|c|c|c|c|c|c|c|}
\hline Source & df & $\begin{array}{l}\text { Grain } \\
\text { Yield } \\
\text { (gm) }\end{array}$ & $\begin{array}{l}\text { Days to } \\
\text { 50\% } \\
\text { Pollen } \\
\text { Shed }\end{array}$ & $\begin{array}{c}\text { Days to } \\
50 \% \\
\text { Silking }\end{array}$ & $\begin{array}{c}\text { Days to } \\
75 \% \\
\text { Brown } \\
\text { Husk }\end{array}$ & $\begin{array}{c}\text { Plant } \\
\text { Height } \\
\text { (cm) }\end{array}$ & $\begin{array}{c}\text { Ear } \\
\text { placement } \\
\text { Height } \\
(\mathbf{c m})\end{array}$ & $\begin{array}{c}\text { Leaf } \\
\text { Width } \\
(\mathbf{c m})\end{array}$ & $\begin{array}{c}\text { Ear } \\
\text { Length } \\
(\mathbf{c m})\end{array}$ & $\begin{array}{c}\text { Ear } \\
\text { Girth } \\
(\mathbf{c m})\end{array}$ & $\begin{array}{c}\text { Kernel } \\
\text { Rows } \\
\text { per } \\
\text { Ear }\end{array}$ & $\begin{array}{l}\text { Kernels } \\
\text { per Row }\end{array}$ & $\begin{array}{c}\text { Test } \\
\text { Weight } \\
\text { (gm) }\end{array}$ \\
\hline Replication & 2.00 & 5.99 & 5.12 & 3.85 & 2.75 & 3.34 & 2.05 & 0.15 & 0.43 & 0.08 & 0.62 & 14.77 & 118.68 \\
\hline Treatments & 27.00 & $506.76^{* *}$ & $6.51 * *$ & $7.48 * *$ & $20.54 * *$ & $3118.55^{* *}$ & $859.12 * *$ & $0.90 * *$ & $2.06 * *$ & $0.74 * *$ & $1.27 * *$ & $24.96^{* *}$ & $822.76 * *$ \\
\hline Error & 54.00 & 17.93 & 2.18 & 2.68 & 5.67 & 26.74 & 26.71 & 0.17 & 0.91 & 0.30 & 0.43 & 6.66 & 178.27 \\
\hline Total & 83.00 & 176.66 & 3.66 & 4.27 & 10.44 & 1031.94 & 296.90 & 0.41 & 1.27 & 0.44 & 0.71 & 12.81 & 386.49 \\
\hline
\end{tabular}

$*$, ** significant at $5 \%$ and $1 \%$ level, respectively

\section{Figures}

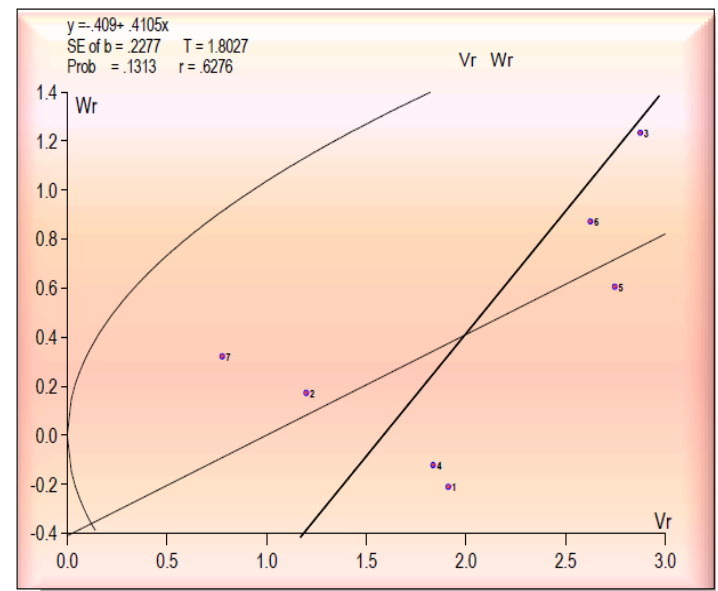

Fig.1 Vr/Wr graph for Days to $50 \%$ pollen shed,

1:V358, 2:V345, 3:V351, 4:CM212, 5:

CML-161, 6: JML-109, 7:V341

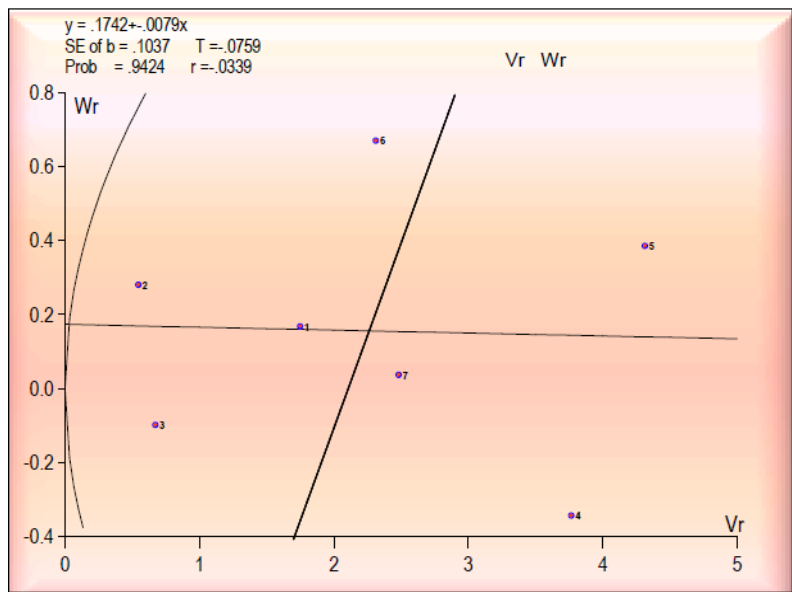

Fig.2 $\mathrm{Vr} / \mathrm{Wr}$ graph for days to $50 \%$ silking 1:

V358, 2: V345, 3: V351, 4: CM212, 5: CML 161, 6: JML-109, 7:V341 


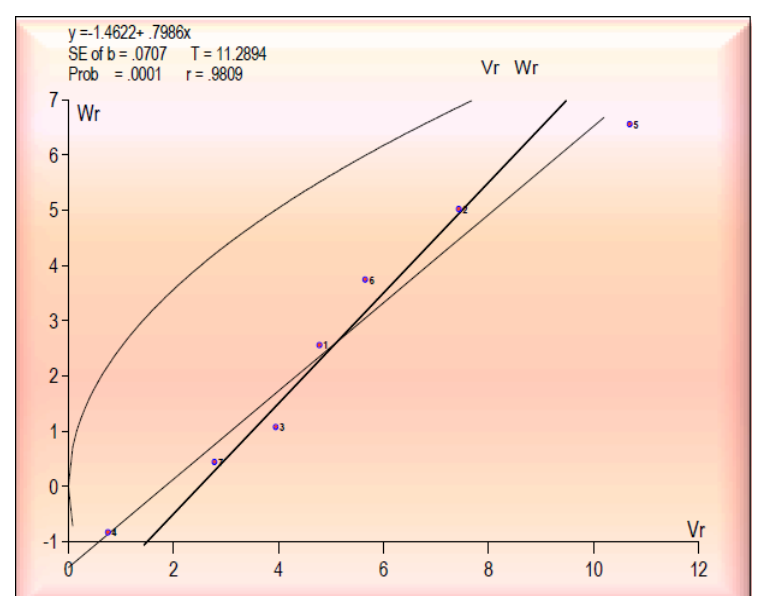

Fig.3 $\mathrm{Vr} / \mathrm{Wr}$ graph for Days to $75 \%$ brown husk, 1:V358, 2:V345, 3:V351, 4:CM212, 5: CML-161, 6: JML-109, 7:V341

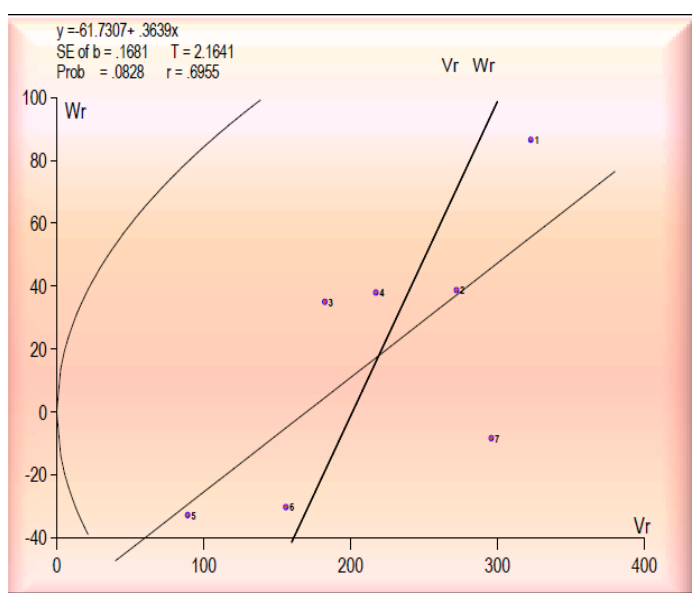

Fig.5 $\mathrm{Vr} / \mathrm{Wr}$ graph for Ear placement height cm, 1:V358, 2:V345, 3: V351, 4: CM212, 5: CML-161, 6: JML-109, 7:V341

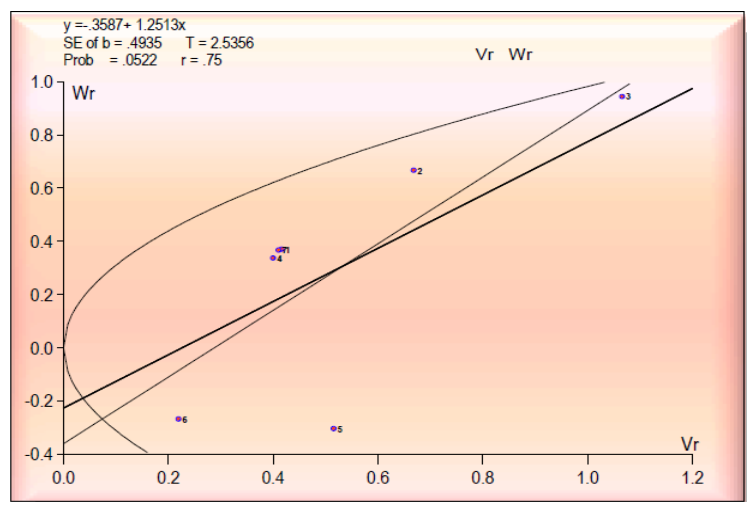

Fig.7 Wr/Vr graph for Ear length $\mathrm{cm}, 1: \mathrm{V} 358$, 2:V345, 3: V351, 4: CM212, 5: CML-161, 6: JML-109, 7:V341

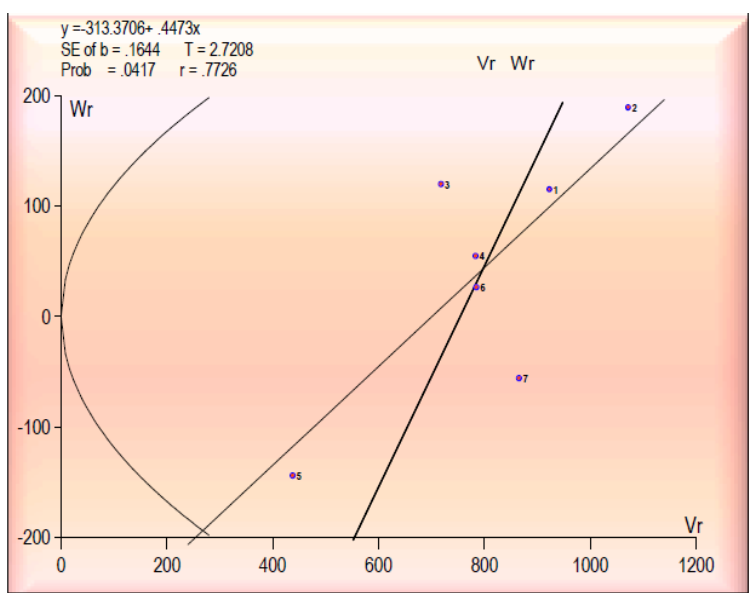

Fig.4 $\mathrm{Vr} / \mathrm{Wr}$ graph for Plant height $\mathrm{cm}, 1$ : V358, 2: V345, 3:V351, 4:CM212, 5: CML161, 6: JML-109, 7:V341

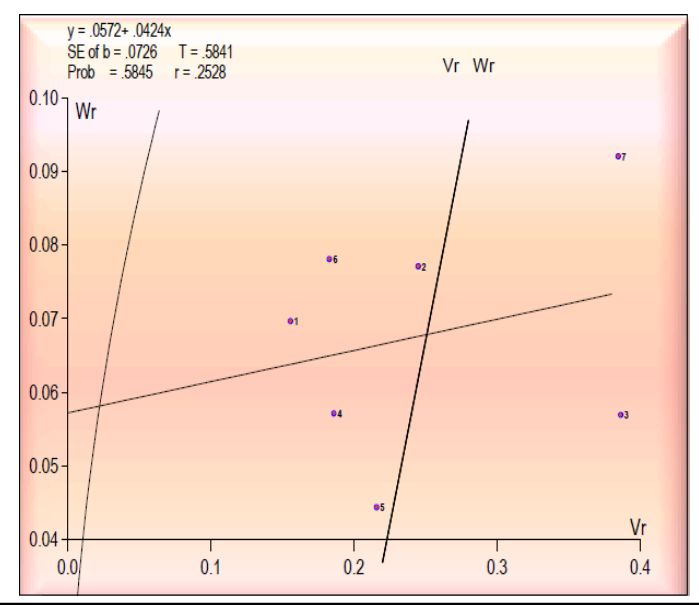

Fig.6 Vr/Wr graph for Ear placement height cm, 1:V358, 2:V345, 3: V351, 4: CM212, 5: CML-161, 6: JML-109, 7:V341

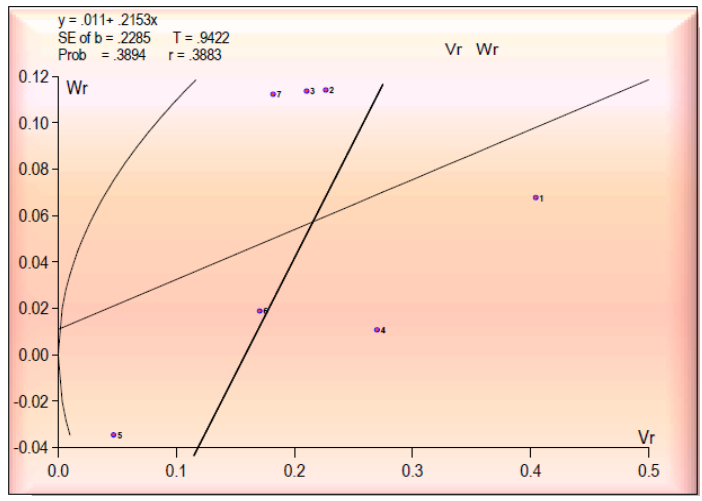

Fig.8 Wr/Vr graph for Ear girth cm, 1:V358, 2:V345, 3: V351, 4: CM212, 5: CML-161, 6: JML-109, 7:V341 


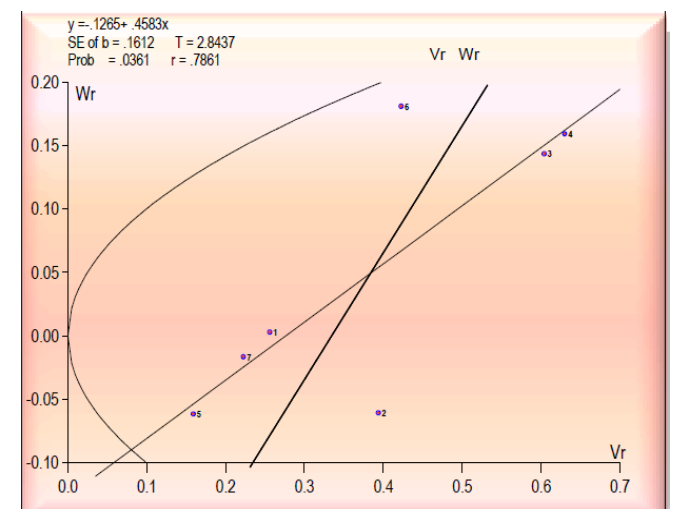

Fig.9 Vr/Wr graph for kernel rows per ear, 1:V358, 2:V345, 3: V351, 4: CM212, 5: CML161, 6: JML-109, 7:V341

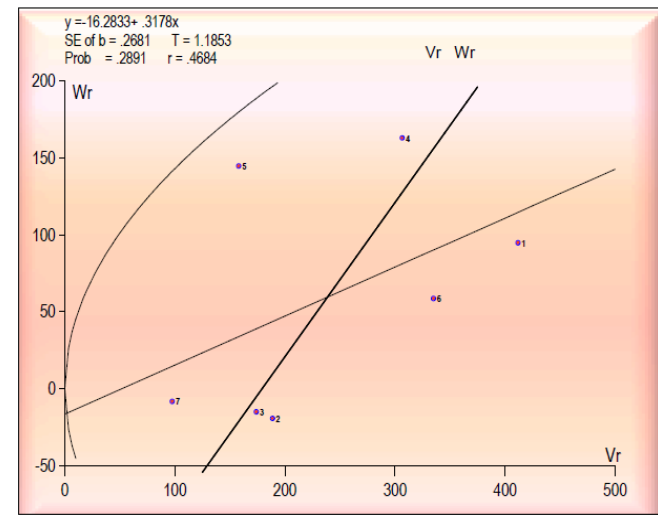

Fig.11 Vr/Wr graph for test weight, 1:V358, 2:V345, 3: V351, 4: CM212, 5: CML-161, 6: JML-109, 7:V341

\section{Kernels per row}

Graphical analysis of the data (Fig. 10) displayed that the intercept of the regression line was negative showing over dominant type of gene action. Distribution of array points depicted that parents CML-161 and V358 had the maximum dominant genes for Kernels per row while (parents V345 and CM212) contained maximum recessive genes. The estimated regression line was deviated significantly from unit slope suggesting presence of non-allelic interaction. These results are compatible with those $\mathrm{Zia}$ and

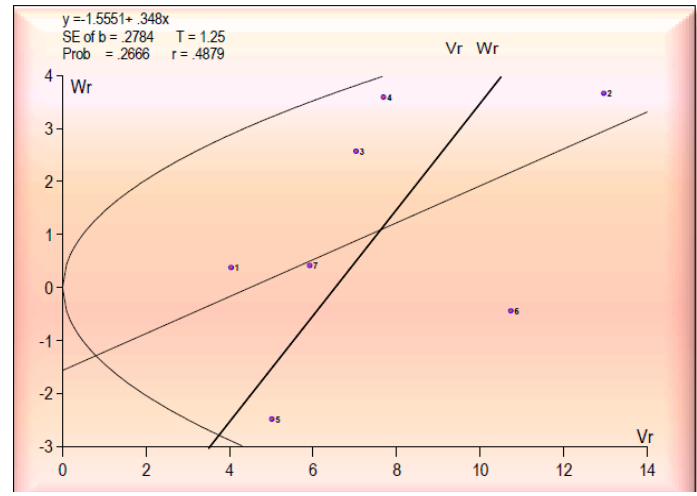

Fig.10 Vr/Wr graph for kernels per row, 1:V358, 2:V345, 3: V351, 4: CM212, 5: CML161, 6: JML-109, 7:V341

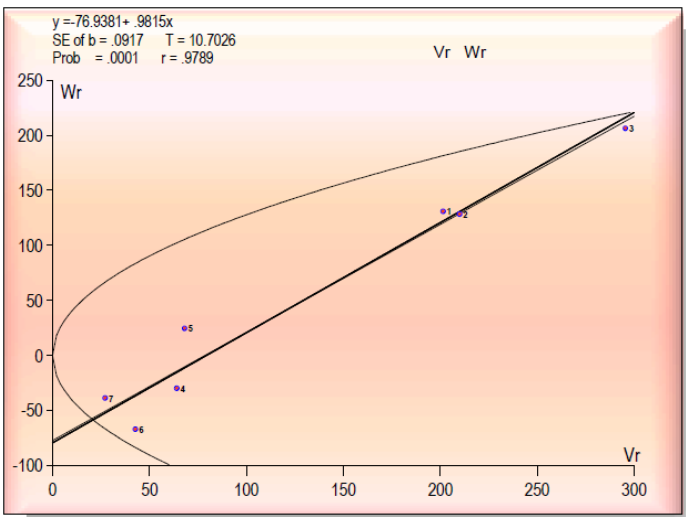

Fig.12 Vr/Wr graph for grain yield, 1:V358, 2:V345, 3: V351, 4: CM212, 5: CML-161, 6: JML-109, 7:V341

Chaudhary, 1980; Singh et al., 1985 and Srdic et al., 2007 who reported that number of kernels per row was conditioned by overdominance type of gene action.

\section{Test weight}

Graphical analysis of the data (Fig. 11) displayed that the intercept of the regression line was negative showing over dominant type of gene action. Distribution of array points depicted that parents V341, V351 and V345 had the maximum dominant genes for test weight while (parents CM212 and V358) 
contained maximum recessive genes. The estimated regression line was deviated significantly from unit slope suggesting presence of non-allelic interaction. The results corroborate the findings of Siddiqui (1988), Naveed (1989) and Perez-Velasquez et al., (1995) who reported that 1000 grain weight per plant was under the control of overdominance type of gene action.

\section{Grain yield}

Graphical analysis of the data (Fig. 12) displayed that the intercept of the regression line was negative showing over dominant type of gene action. Distribution of array points depicted that parents V341 and JML109 had the maximum dominant genes for grain yield while (V351) contained maximum recessive genes. The estimated regression line was not deviated significantly from unit slope suggesting absence of non-allelic interaction. The results corroborate the findings of Siddiqui (1988), Naveed (1989) and PerezVelasquez et al., (1995) who reported that grain yield per plant was under the control of over-dominance type of gene action.

\section{Acknowledgements}

The authors are thankful to the AICRP maize centre Udampur for supplying seed material to conduct this research.

\section{References}

Hayman, B.I. 1954. The theory and analysis of diallel cross-I. Genetics, 32: 789809.

Hussain, I, Ahsan, M., Saleem, M. and Ahmad, A. 2009. Gene action studies for agronomic traits in maize under normal and water stress conditions. Pak. J. Agri. Sci., 46(2): 107-112.

Jinks, J.L. 1954. The analyses of continuous variation of a diallel cross of Nicotiana rustica L. Genetics, 39: 767-788.

Mather, K. and Jinks, J.L. 1971. Biometrical Genetics, 3 Ed. Chapman and Hall, London, pp: 382.

Naveed, A. 1989. Genetic analysis of yield and origin, had most recessive genes. These results are in economic characters in maize diallel crosses. M.Sc. (Hons). Thesis, Dept. Plant Breeding and Genetics, Univ. of Agric., Faisalabad

Perez-Velasquez, J.C., H. Ceballos, S. Pandey and C. Diaz-Amaris. 1995. Analysis of diallel crosses among Colombian land-races and improved populations of maize. Crop Sci., 35(2): 572-578.

Rafiq, M., M.A. Zafar and M. Afzal, 1993.Detection of gene action responsible for plant height in maize inbreds through diallel crossing system. J. Agric. Res., 31(3): 287293.

Rana, M. K. and Kapoor, V. 2009.Combining ability analysis for yield and some growth characters in maize (Zea mays L.). Indian J. Agri. Res., 37(3): 219-222.

Siddiqui, N.A., 1988. Genetic analysis of grain yield and its components in maize diallel crosses. M.Sc. (Hons). Thesis, Dept. Plant Breeding and Genetics, Univ. of Agric., Faisalabad.

Singh, H., A.S. Khehra and B.S. Dhillon, 1985. Genetic architecture of two heterotic populations of maize. Maydica 30(1): 31-36, PI. Br. Absts., 55(10): 7752-01985.

Srdic, J., Z. Pajic and S. Drinic-Mladenovic, 2007. Inheritance of maize grain yield components. Maydica, 52(3): 261-264.

Zia, M.K. and A.R. Chaudhry, 1980. Gene action for yield and yield components in maize. Pak. J. Agri. Sci., 17(2): 87-92.

\section{How to cite this article:}

Padma Lay and Razdan, A.K. 2017. Genetic Analysis of Grain Yield and its Components of Maize (Zea mays L.) Inbred Lines. Int.J.Curr.Microbiol.App.Sci. 6(7): 1366-1372. doi: https://doi.org/10.20546/ijcmas.2017.607.163 